\title{
PERJANJIAN PERKAWINAN DAN URGENSINYA BAGI PEREMPUAN
}

\author{
Afiq Budiawan \\ Pasca Sarjana UIN Maliki Malang \\ Email:bud_f25@yahoo.com \\ Telepon: 085646655717
}

\begin{abstract}
Prenuptial agreement legal status is applicable legally in a marriage. The main aim of it is for preventive action to overcome conflict, to minimize (to make it as handicap for) divorce, to complete the divorce statement, to guarantee wife's right and to protect wife from husband's discrimination and husband's harmful authority. The agreement also aims at mediating spouse's problem to solve the problem in a very short time.

Status hukum perjanjian perkawinan bersifat legal untuk diterapkan dalam suatu pernikahan. Tujuan utama dari perjanjian perkawinan ini adalah sebagai tindakan preventif untuk mengatasi terjadinya konflik, meminimalkan (mempersulit) perceraian, penyempurna dari ta'lik talak, menjamin hak-hak istri dan sekaligus dapat melindungi mereka dari perlakuan diskriminatif dan sewenang- wenang laki-laki (suami). Perjanjian tersebut juga bertujuan sebagai mediasi bagi masalah antara suami dan istri sehingga bisa diselesasikan dalam waktu singkat.
\end{abstract}

Keywords: perjanjian dan perkawinan, hak-hak suami-istri

\section{Pendahuluan}

Perjanjian kawin dibuat oleh calon suami istri yang akan melangsungkan perkawinan. Di negara kita yang masih menjunjung tinggi adat ketimuran, menjadi persoalan yang sensitif ketika salah seorang calon pasangan berniat mengajukan untuk membuat perjanjian pranikah (prenuptial agreement) dan dinilai tidak lazim dan dianggap tidak biasa. Karena pernikahan selama ini dianggap sebagai sesuatu yang sakral, maka perjanjian pranikah masih dianggap sebagai urusan duniawi yang 
tidak sepantasnya dibicarakan dan dilakukan. Perjanjian perkawin bukan persiapan untuk bercerai, melainkan dibuat untuk menjaga profesionalisme, hubungan, citra suami dan istri.

Undang-Undang No 1 tahun 1974 tetang Perkawinan tidak secara tegas memberikan definisi mengenai perjanjian perkawinan (Nuruddin dkk, 2004). Serta "Perjanjian" yang dimaksud dalam Pasal 29 UU No 1 Tahun 1974 tidak termasuk ta 'lik talak. Hukum Islam mengenai perjanjian perkawinan tidak diatur secarak husus seperti halnya perjanjian perkawinan yang terdapat di dalam Kitab Undang-Undang Hukum Perdata. Dengan membuat perjanjian perkawinan, suami istri mempunyai kesepatan untuk saling terbuka. Mereka dapat membagi rasa atas keinginan-keinginan yang hendak disepakati tanpa harus merugikan salah satu pihak. Perjanjian perkawinan tidak hanya sebatas masalah harta/uang, ada hal lain yang penting dan perlu diperjanjikan, misalnya kekerasan dalam rumah tangga, suami yang tidak bertanggung jawab, dan lain-lain.

Perjanjian perkawinan sifat dan status hukumnya tidak wajib dan tidak diharamkan. Perjanjian perkawinan itu mubah (boleh-boleh saja). Perjanjian perkawinan ini dapat dijadikan sebagai tindakan preventif untuk mengatasi terjadinya konflik sebelum melakukan perkawinan, sarana untuk meminimalkan (mempersulit) perceraian, serta penyempurna dari ta'lik talak yang selama ini dianggap tidak merefleksikan keinginan-keinginan istri, menjamin hak-hak mereka, dan melindungi mereka dari perlakuan diskriminatif dan sewenang- wenang laki-laki (suami).

\section{Perjanjian Perkawinan dalam Perspektif Fiqih dan UU}

Perkawinan adalah sunatullah yang berlaku bagi semua umat manusia guna melangsungkan hidupnya dan untuk membentuk rumah tangga. Karena rumah tangga adalah bangunan yang paling fital dalam pembentukan struktur sosial masyarakat dan umat secara keseluruhan (Al-Mashri, 2011), maka agama Islam sangat menganjurkan perkawinan. Sedangkan dalam Pasal 2 Kompilasi Hukum Islam(KHI) bahwa perkawinan menurut hukum Islam adalah pernikahan, yaitu akad yang kuat atau miitzaaqah ghaliidhan untuk mentaati perintah Allah dan melakukannya merupakan ibadah. Perkawinan bertujuan untuk mewujudkan kehidupan rumah tangga yang sakinah, mawaddah dan rohmah. 
Kata miitzaaqan qhaliidhan ini ditarik dari firman Allah SWT dalam Surat An-Nisa Ayat 21

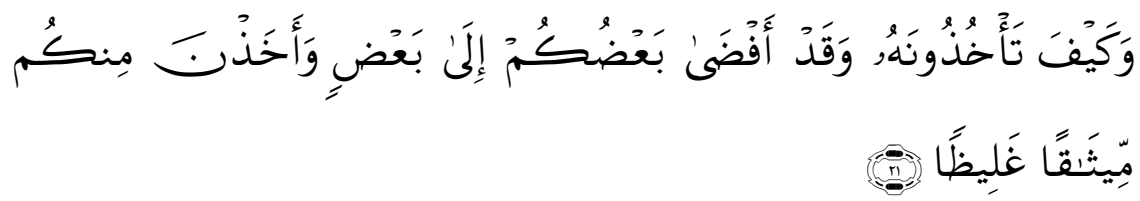

Artinya. Bagaimana kamu akan mengambilnya kembali, padahal sebagian kamu Telah bergaul (bercampur) dengan yang lain sebagai suami-istri. dan mereka (istri-istrimu) Telah mengambil dari kamu perjanjian yang kuat. (An-Nisa: 21)

Dalam tafsir Ibnu Katsir (Jus 4), diriwayatkan dari Ibn Abbas Mujahid dan Said bi Jubair bahwa yang dimaksud perkawinan adalah akad, Sufyan ats Tsauri berkata dari Habib bin Abi Tsabit, dari Ibnu Abbas, yaitu miitzaaqan ghaliidhan diartikan sebagai mempertahankan dengan ma'ruf atau melepaskannya dengan ihsan. Maksud perkataan nikah sebagaimana yang terdapat pada ayat tersebut yang berarti bukan merupakan perjanjian yang biasa melainkan suatu perjanjian yang kuat.

Menurut Abdulkadir Muhammad, perjanjian adalah suatu persetujuan dimana dua orang atau lebih saling mengikatkan diri untuk melaksanakan suatu hal dalam lapangan harta kekayaan (Muhammad, 1990). R. Subekti, menyatakan "perjanjian adalah suatu peristiwa dimana seseorang berjanji kepada orang lain atau di mana 2 (dua) orang itu saling berjanji untuk melaksanakan sesuatu hal, yang dalam bentuknya perjanjian itu dapat dilakukan sebagai suatu rangkaian perkataan yang mengandung janji-janji atau kesanggupan yang diucapkan secara lisan maupun tertulis" (Subekti, 1994).

Dasar berlakunya hukum Islam khusus mengenai Hukum Perkawinan, Talak dan Rujuk ialah S.1937 No. 638 jo. S. 1937 No. 610 dan No. 116 jo. Peraturan Pemerintah No. 45 Tahun 1957 jo. Undang-undang No. 22Tahun 1946 jo. Undang-undang No. 32 Tahun 1974, sekarang Undang-undang Nomor 1 Tahun 1974 (lembar Negara Tahun 1974 Nomor 1) dan Kompilasi Hukum Islam (Instruksi Presiden RI Nomor 1 Tahun 1991 jo. SK Menteri Agama No. 154 Tahun 1991).

Dalam Pasal 1 huruf e Kompilasi Hukum Islam dinyatakan perjanjian perkawinan adalah perjanjian yang diucapkan calon mempelai 
pria setelah akad nikah yang dicantumkan dalam Akta Nikah berupa janji talak yang digantungkan kepada suatu keadaan tertentu yang mungkin terjadi di masa yang akan datang.

Rumusan definisi perjanjian perkawinan yang disebutkan dalam Kompilasi Hukum Islam lebih bersifat universal-konsepsional, yang tidak mencampur-adukkan antara kebijakan yang sifatnya temporal dengan konsep dasar perjanjian perkawinan yang sifatnya permanen dan universal. Pengertian perjanjian perkawinan yang dikemukakan dalam berbagai doktrin fikih pada umumnya menempatkan ta'lik talak searah dengan perjanjian/ ta'lik talak, dalam pengertian bahwa ta'lik talak yang diucapkan oleh suami tidak perlu memperoleh persetujuan dari istri, Pengertian ta'liktalak seperti ini tidak sejalan dengan asas perkawinan di Indonesia yang menempatkan suami-istri pada derajat yang sama (Daud Ali, 1999).

Menurut Kholil Rahman terdapat macam-macam sifat perjanjian, yaitu; 1) Syarat-syarat yang menguntungkan istri, seperti syarat untuk tidak dimadu. Para ulama berbeda pendapat dalam masalah ini ada yang mengatakan sah dan ada yang mengatakan tidak sah. 2) Syarat-syarat yang bertentangan dengan apa yang di kehendaki oleh maksud akad itu sendiri. Seperti tidak boleh mengadakan hubungan kelamin, tidak ada hak waris di antara suami istri, tidak boleh berkunjung kepada kedua orang tua, dan lain-lain. Syarat-syarat semacam itu tidak sah dan tidak mengikat. 3) Syarat-syarat yang bertentangan dengan ketentuan syara', seperti jika akad nikah sudah dilangsungkan, agar masing-masing pindah agama, harus makan daging babi, dan sebagainya. Perjanjian semacam ini tidak sah, dan bahkan akad nikahnya juga tidak sah (Sayid Sabiq, Fiqh Sunnah, Juz II, Beirut, Dar al-Fikr, 1983: 114).

Apabila perjanjian yang telah disepakati bersama antara suami dan istri, tidak dipenuhi oleh salah satu pihak, maka pihak lain berhak untuk mengajukan persoalannya ke Pengadilan Agama untuk menyelesaikannya. Dalam hal pelanggaran dilakukan suami misalnya istri berhak meminta pembatalan nikah atau sebagai alasan perceraian dalam gugatannya. Demikian juga sebaliknya jika si istri yang melanggar perjanjian di luar ta'lik talak, suami berhak mengajukan perkaranya ke Pengadilan Agama (Rofiq, 2003). 
Mengenai perjanjian ta'lik talak sebagai perjanjian perkawinan dalam Kompilasi Hukum Islam ini diatur dalam Pasal 46 yang menyebutkan bahwa; 1) Isi taklik talak tidak boleh bertentangan dengan hukum Islam. 2) Apabila keadaan yang disyaratkan dalam taklik talak betul-betul terjadi kemudian, tidak dengan sendirinya talak jatuh. Supaya talak benar-benar jatuh, istri harus mengajukan persoalannya ke Pengadilan Agama. 3) Perjanjian taklik talak bukan suatu perjanjian yang wajib diadakan pada setiap perkawinan, akan tetapi sekali taklik talak sudah diperjanjikan tidak dapat dicabut kembali.

Akad dalam terminologi fikih sebagaimana disebut al-Zarqa adalah ikatan secara hukum yang dilakukan oleh dua atau beberapa pihak yang sama-sama berkeinginan untuk mengikat diri" (Aziz, 2000). Ali AlSayis memberikan komentar lebih lanjut bahwa perjanjian dalam Islam itu bukan hanya perjanjian yang bersifat partai, tetapi juga termasuk perjanjian sepihak, bahkan juga termasuk janji kepada Tuhan (Muhammad Ali alSayis, tt, Tafsir Ayat al-Ahkam, (Juz II, tp, ttp): 154).

Rumusan perjanjian yang dikemukakan al-Zarqa adalah dalam konteks perjanjian yang bersifat partai. Oleh karena itu menurutnya, untuk sahnya suatu perjanjian harus dipenuhi delapan persyaratan, yaitu; 1) Cakap kedua belah pihak yang berakad. 2) Obyek yang diperjanjikan diakui keabsahannya oleh syara. 3) Akad yang dilakukan tidak dilarang oleh syara. 4) Akad yang dilakukan memenuhi syarat khusus yang diperjanjikan. 5) Akadnya bermanfaat menurut syara. 6) Ijab tetap utuh dan sahih sampai terjadinya kabul. 7) Ijab dan kabul dilakukan dalam satu majelis. 8) Tujuan akad itu jelas dan diakui oleh syara(Aziz, 2000).

Dalam fiqih Sunnah, Sayid Sabiq menguraikan bahwa perjanjian perkawinan yang disebut sebagai ta'lik talak ada dua macam bentuk; 1) Ta'lik yang dimaksud sebagai janji, karena mengandung pengertian melakukan pekerjaan atau meninggalkan suatu perbuatan atau menguatkan suatu kabar. Dan ta'lik talak seperti ini disebut dengan ta'liq qasami. 2) Ta'lik yang dimaksudkan untuk menjatuhkan talak bila telah terpenuhi syarat ta'liq. Ta'liq seperti ini disebut dengan ta'liq syarti. Dari kedua bentuk ta'lik talak di atas dapat dibedakan dengan kata-kata yang diucapkan oleh suami. Pada ta'liq qasamy, suami bersumpah untuk dirinya sendiri. Sedangkan pada ta'lik talak suami mengajukan syarat dengan maksud jika 
syarat tersebut ada maka jatuhlah talak suami pada istrinya. Ulama berbeda pendapat tentang jatuh atau tidaknya talak dengan dua formulasi di atas.

Jumhur Ulama berpendapat bahwa dua bentuk ta'lik yang dikaitkan dengan talak/janji, apabila yang dita'likkan terjadi maka talaknya jatuh (Zakiyuddin Sya'ban, al-Ahkam al-Syar'iyah li af-Ahwal al-Syakhsiyah, al-Nahdah al-Arabiyah, (Mesir, 1967): 442). Sedangkan Ibn Hazm dan Ibn Qayyim al-Jauziyah berpendapat bahwa ta'lik yang di dalamnya terkandung maksud sumpah (qasam) tidak berakibat jatuhnya talak, akan tetapi wajib membayar kifarat sumpah dan ta'lik yang di dalamnya terkandung syarat yang dimaksudkan untuk menjatuhkan talak ketika terjadinya sesuatu yang disyaratkan, maka talak tersebut jatuh.

Terlepas dari perbedaan pendapat di kalangan fuqaha tentang bentuk ta'lik yang jatuhnya talak, tetapi menurut A. Jamil Latief bahwa perbedaan yang mendasar antara ta'lik yang ada dalam kitab fikih, dengan yang ada di Indonesia kalau dalam fikih suami sebagai subyek talak sedangkan ta'lik di Indonesia istri lah yang menjadi subyek talak.

Kompilasi Hukum Islam memberikan kebebasan kepada kedua belah pihak untuk merumuskan sendiri apa yang akan diperjanjikan sebagaimana diatur dalam pasal 45 yang menyatakan bahwa kedua belah pihak dapat mengadakan perjanjian perkawinan dalam bentuk ta'lik talak dan selanjutnya pasal 46 menjelaskan bahwa isi perjanjian perkawinan batasannya hanyalah tidak boleh bertentangan dengan hukum Islam.

Dalam KUHPerdata pengertian perkawinan tidak dengan tegas diatur ketentuan yang mengatur mengenai perkawinan seperti Pasal 26 memandang soal perkawinan hanya dalam hubungan-hubungan perdata. Perkawinan dapat dianggap sebagai suatu perjanjian (persetujuan), asalkan adanya kehendak yang sesuai antara seorang pria dengan seorang wanita serta adanya kehendak tersebut (Pasal 28 KUHPerdata).

Perkawinan menurut Undang Undang No 1 Tahun 1974 dirumuskan dalam Pasal 1 yang berbunyi : Perkawinan ialah ikatan lahir batin antara seorang pria dengan seorang wanita sebagai suami istri dengan tujuan membentuk keluarga yang bahagia dan kekal berdasarkan Ketuhanan Yang Maha Esa.

Perjanjian dalam perkawinan bukan merupakan sembarang perjanjian. Perjanjian dalam perkawinan tidak sama dengan perjanjian 
pada umumnya misalnya dalam perjanjian sewa menyewa, tukar menukar dan jual beli, dimana masing-masing pihak bebas mengadakan perjanjian untuk menentukan isi dari perjanjian tersebut. Perjanjian perkawinan adalah persetujuan yang dibuat oleh kedua calon mempelai pada waktu atau sebelum perkawinan dilangsungkan, dan masing-masing berjanji akan mentaati apa yang akan disebut dalam persetujuan itu, yang disahkan oleh pegawai pencatat nikah (Ghanaly, 2006).

1. Undang-undang Nomor 1 Tahun 1974 Pasal 29 menyatakan sebagai berikut: a) Pada waktu atau sebelum perkawinan dilangsungkan kedua belah pihak atas persetujuan bersama dapat mengadakan perjanjian tertulis yang disahkan oleh Pegawai Pencatat Perkawinan, setelah mana isinya berlaku juga terhadap pihak ketiga, sepanjang pihak ketiga tersangkut. b) Perjanjian tersebut tidak dapat disahkan bilamana melanggar batas-batas hukum, agama dan kesusilaan. c) Perjanjian tersebut mulai berlaku sejak perkawinan dilangsungkan. d) Selama perkawinan berlangsung perjanjian tersebut tidak dapat dirubah, kecuali bila dari kedua belah pihak ada persetujuan untuk merubah dan perubahan tidak merugikan pihak ketiga.

Sebenarnya Undang-Undang No. 1 Tahun 1974 tentang Perkawinan tidak mengatur secara tegas tentang perjanjian perkawinan, dalam UU yang hanya dinyatakan bahwa kedua belah pihak dapat mengadakan perjanjian tertulis yaitu perjanjian perkawinan. dalam hal ketentuan ini tidak disebutkan batasan jelas, bahwa perjanjian perkawinan itu dalam hal apa. Sehingga dapat dikatakan bahwa dalam UU No. 1 Tahun 1974 ini sangat luas dan menyangkut banyak hal (Meliala, 2006).

Unsur-unsur perjanjian kawin menurut Pasal 139 KUHPerdata, yaitu: 1) Perjanjian, 2) Calon suami/istri, 3) Mengatur akibat perkawinan, dan 4) Mengenai harta kekayaan. Adapun asas-asas perjanjian yang dikenal dalam hukum perdata antara lain adalah: pertama, asas pacta sun servanda menyatakan bahwa perjanjian yang dibuat secara sah berlaku sebagai undang-undang. Asas ini terdapat dalam Pasal 1338 ayat (1) Kitab Undang-Undang Hukum Perdata yang berbunyi : "Semua persetujuan yang dibuat secara sah berlaku sebagai undang- undang bagi mereka yang membuatnya" Dari bunyi Pasal 1313 Kitab Undang-Undang Hukum Perdata 
tersebut, maka dapat dikatakan bahwa para pihak harus melaksanakan perjanjian tersebut berupa prestasi bagi pihak lainnya. Jika salah satu pihak dalam perjanjian tersebut tidak melaksanakan perjanjian, pihak lain dalam perjanjian berhak untuk menagih atau memaksakan pelaksanaannya melalui mekanisme dan jalur hukum yang berlaku (Badrulzaman, 2001).

Kedua, asas konsensualisme, pengertian asas konsensualisme adalah pada dasarnya perjanjian dan perikatan yang timbul karenanya itu sudah dilahirkan sejak detik tercapainya kesepakatan. Dengan kata lain perjanjian itu sudah sah apabila sudah sepakat mengenai hal-hal yang pokok dan tidaklah diperlukan sesuatu formalitas. Asas konsensualisme terdapat dalam Pasal 1320 Kitab Undang-Undang Hukum Perdata yang menyatakan bahwa, "untuk sahnya perjanjian diperlukan empat syarat; sepakat mereka yang mengikat dirinya, kecakapan untuk membuat suatu perjanjian, suatu hal tertentu, dan suatu sebab yang halal.

Ketiga, asas kebebasan berkontrak. Sebagaimana dalam asas konsensualisme, maka asas kebebasan berkontrak dapat ditemukan pada Pasal 1320 Kitab Undang-Undang Hukum Perdata. Asas tersebut terdapat dalam Pasal 1320 ayat (4). Ketentuan ayat (4) dalam Pasal 1320 Kitab Undang-Undang Hukum Perdata tersebut menunjukkan adanya pernyataan bahwa setiap orang bebas membuat perjanjian sepanjang prestasi (Mulyadi dkk) yang dilakukan tidak dilarang. Mengenai sebab yang dilarang disebutkan dalam Pasal 1337 Kitab Undang-Undang Hukum Perdata yang berbunyi: "Suatu sebab adalah terlarang apabila dilarang oleh undangundang atau apabila berlawanan dengan kesusilaan atau ketertiban umum".

Keempat, asas kepercayaan. Seseorang yang melakukan perjanjian dengan pihak lain berarti menumbuhkan kepercayaan di antara kedua pihak itu, bahwa satu sama lain akan memegang janjinya atau dengan kata lain akan memenuhi prestasi di belakang hari. Kelima, asas kekuatan mengikat. Perjanjian mempunyai kekuatan mengikat para pihak. Terikatnya para pihak dalam perjanjian tidak semata terbatas pada apa yang diperjanjikan, namun juga terhadap beberapa unsur lain sepanjang dikehendaki oleh kebiasaan, kepatutan dan moral. Hal ini, merupakan implementasi asas Pacta Sun Servanda yang terdapat dalam Pasal 1338 ayat (1) KUHPerdata, menyatakanbahwa perjanjian yang dibuat secara sah berlaku sebagai undang-undang. Asas Persamaan Hukum Asas persamaan hukum berarti 
menempatkan para pihak dalam perjanjian sama derajatnya dan tidak terdapat perbedaan derajat apapun. Oleh karena terdapat persamaan, maka masing-masing pihak diharuskan menghormati satu sama lainnya.

Keenam, asas keseimbangan. Asas keseimbangan yang menghendaki kedua pihak memenuhi dan melaksanakan perjanjian dengan baik. Asas Kepastian Hukum Perjanjian sebagai sebuah undang-undang harus mengandung kepastian hukum. Kepastian hukum dalam perjanjian dapat disimak dari kekuatan mengikatnya perjanjian yaitu sebagai undangundang bagi para pihak.

Ketujuh, asas moral. Sutau perbuatan sukarela dari seseorang tidak akan menimbulkan hak apapun bagi orang tersebut untuk menuntut prestasi dari pihak lainnya. Namun demikian seseorang yang melakukannya dengan sekarela tersebut justru mempunyai kewajiban untuk meneruskan dan menyelesaikan perbuatan itu dengan baik. Kedelapan, asas kepatutan Kepatutan yang dimaksud dalam perjanjian adalah bahwa hubungan hukum antara para pihak dalam bentuk perjanjian itu juga harus memperhatikan rasa keadilan masyarakat.

Dalam hal membuat perjanjian perkawinan yang perlu dipertimbangkan adalah: 1) Keterbukaaan dalam mengungkapkan segala hal secara detail seperti kondisi keuangan baik sebelum dan sesudah pernikahan, tidak melakukan kekerasan dalam rumah tangga, dan ketika suami yang tidak bertanggung jawab, dan lain-lain. 2) Kerelaan perjanjian perkawinan harus disetujui dan di tanda tangani oleh kedua belah pihak secara suka rela tanpa paksaan. Jika salah satu pihak merasa dipaksa, perjanjian perkawinan bisa diancam batal karenanya. 3) Pilih lah pejabat berwenang yang obyektif, sehingga dalam membuat isi perjanjian perkawinan bisa tercapai keadilan kedua belah pihak. 4) Perjanjian perkawinan hendaknya tidak dibuat dibawah tangan, tetapi harus disahkan di notaris.

\section{Urgenitas Perjanjian Perkawinan bagi Perempuan}

Urgensi perjanjian perkawinan adalah menjamin hak-hak wanita (istri) dan melindungi mereka dari perlakukan diskriminatif dan sewenang-wenang laki-laki (suami). Serta dapat mengatur penyelesaian dari masalah yang timbul selama perkawinan, antara lain yang pertama, dapat menimbulkan sikap saling terbuka antar pasangan dalam hal keuangan. Masing-masing pihak dapat mengekspresikan kemauannya 
seperti menghindari sifat boros salah satu pasangan. Adanya perjanjian ini dapat menyelamatkan rumah tangga perkawinan mereka nantinya.

Kedua, menghindari dari maksud buruk salah satu pasangan. Seringkali pernikahan menjadi suatu sarana untuk memperoleh keuntungan atau kekayaan dari pihak lain. Menikah kemudian mengajukan gugatan cerai untuk mendapatkan harta gono gini. Dengan adanya perjanjian pra nikah ini maka akan melindungi harta benda dari rebutan pihak lain.

Ketiga, tanggung jawab terhadap anak-anak hasil pernikahan tersebut terutama mengenai biaya hidup anak, dan biaya pendidikan harus diatur sedemikian rupa. Dengan tujuan agar kesejahteraan anak dapat terpenuhi.

Keempat, istri dan anak dan anak dapat terhindar dari prilaku semenamena suami yang tidak bertanggung jawab. Misalnya bagi perempuan WNI yang menikah dengan lelaki WNA, sebaiknya mereka memiliki perjanjian pra nikah, untuk memproteksi diri mereka sendiri. Serta perjanjian ini dapat pula memuat mengenai kewarganegaraan anak yang nantinya dilahirkan dari perkawinan campuran, bahwa anak yang nantinya dilahirkan akan mengikuti kewarganegaraan ibu dengan pertimbangan-pertimbangan tertentu, misalnya pekerjaan ibu yang berlokasi di Indonesia.

Kelima, istri terhindar dari adanya kekerasan dalam rumah tangga, bisa dalam artian fisik ataupun psikis, misalnya istri bisa mengembangkan kemampuannya dengan boleh bekerja, menuntut ilmu lagi, dll Karena tidak jarang terjadi ketidakseimbangan dalam berinteraksi antara suami dan istri, salah satu pasangan mendominasi yang lain sehingga terjadi perasaan yang terendahkan dan terkekang dalam berekspresi.

\section{Kesimpulan}

Perjanjian perkawinan belum banyak dipraktikkan oleh wanita muslim, berdasarkan pada peraturan perundang-undangan Indonesia dan hukum fiqih memperbolehkan untuk itu. Sangat sah bagi wanita untuk membuat syarat-syarat tertentu dalam lembaran perjanjian perkawinan kepada suami, sepanjang tidak melanggar syariat. Apalagi perjanjian perkawinan dimaksudkan untuk memberi kejelasan hak dan kewajiban bagi suami istri dalam berkeluarga agar tercipta hubungan harmonis. 


\section{DAFTAR PUSTAKA}

Al-Mashri. Syaikh Mahmud. 2011. Bekal Pernikahan. Jakarta: Qisthi Perss.

Badrulzaman, Mariam Darus. 2001. Kompilasi Hukum Perikatan. PT Citra Aditya Bakti.

Aziz, Abdul Dahlan (Ed). 2000. Ensiklopedi Hukum Islam. Jakarta : PT. Ichtiar Baru vanHoeve, Jilid I, Cet. IV.

Daud Ail, Mohammad. 1999. Hukum Islam Pengantar ilmu Hukum dan Tata Hukum Islam diIndonesia. Jakarta : PT. Raja Grafindo Persada, Cet. VII, Ed. VI .

Meliala, Djaja S. 2006. Perkembangan Hukum Perdata Tentang Orang dan Hukum Keluarga. Bandung: Nuansa Aulia.

Muhammad, Abdulkadir. 1990. Hukum Perikatan. Bandung : Citra Aditya Bhakti.

Mulyadi, Kartini, Gunawan Widjaja. Perikatan Yang Lahir Dari Perjanjian. Jakarta: Raja Grafindo Persada.

Nuruddin, Amiur \& Tarigan, Azhari Akmal. 2004. Hukum Perdata Islam di Indonesia. Jakarta: Kencana, Cet II.

Rofiq, Ahmad. 2003. Hukum Islam di Indonesia. Jakarta: Raja Grafindo Persada

Subekti, R. 1994. Hukum Perjanjian. Jakarta: PT. Intermasa.

Ghanaly, Abd Rahman. 2006. Fiqih Munakahat. Jakarta: Kencana.

Sya'ban, Zakiyuddin. 1967. al-Ahkam al-Syar'iyah li af-Ahwal alSyakhsiyah, al-Nahdah al-Arabiyah. Mesir. 